\title{
The Development of the Chinese Insurance Industry: Its Structure, Performance and Future
}

\author{
by Y. M. Niu*
}

\begin{abstract}
This paper assesses the development of the Chinese insurance industry over the last ten years or so. Its market structure, competition situation, as well as the performance of the People's Insurance Company of China (PICC) are reviewed. Detailed discussion is provided of the Draft Insurance Law of China, in order to evaluate the present and future legislation and regulatory environment in the market. Attention is also paid to the insurance education and training and the opening up to foreign insurance forces. Finally, the paper ends with a discussion of the strengths and weaknesses of the Chinese insurance industry and its ability to respond to future challenge.
\end{abstract}

Key words :

Chinese insurance market, insurance development, insurance legislation.

\section{Introduction}

The opening up and economic restructuring of China in 1979 resuscitated the insurance industry, which had been at a virtual interruption since the cultural revolution of the 1960 's have. The following ten years or so has seen an astonishing growth in this sector.

In line with the expansion of the Chinese economy and the deepening of its transformation towards a market-oriented economy, the radical and fundamental financial reform is on its way. The modernization of the Chinese insurance industry appears high on the government agenda.

The purpose of this paper is to provide a general picture of the level, distribution and pattern of growth in the Chinese insurance market over the past ten years, and to discuss its strengths and weaknesses in its ability to respond to future challenges.

* The author is a doctoral student in the School of Management and Finance, University of Nottingham. The paper is partly sponsored by the Geneva Association and the Association of British Insurers (ABI). An early version was presented at the 5th Annual Conference of the Chinese Economic Association (UK), December 1993, London. The author would like to thank in particular Dr. S. Diacon, University of Nottingham, for his rigorous revisions and precious comments. Mr. A. Tudor of the Chartered Insurance Institute, Comments provided by Dr. N. Gemmell of University of Nottingham, Mr. N. Wolfers of Eagle Star, and Mr. I. Toms of Sun Alliance are also warmly acknowledged. The author alone is responsible for any omission and error in the paper, which reflects the situation as of February 1994. 
The paper will proceed in five parts. After the introduction, section 2 provides an overall picture of the Chinese insurance industry's development over the last ten years. The market and managerial performance of the quasi-monopolist People's Insurance Company of China (PICC) will be discussed in depth. Section 3 deals with the insurance legislation and regulation issues in China, concentrating on the insurance laws draft of China, which have yet to be approved by the Chinese government. The linkage and involvement with foreign insurance forces is discussed in section 4 , and a summary is provided in an appendix. Finally, in section 5, the possible evolution of the Chinese insurance industry will be outlined.

\section{Structure and performance of the Chinese insurance industry}

The history of insurance in China dates back thousands of years, to merchants, mainly along the Yangtze River, who agreed to share the loss of vessel or cargo in proportion to the amount of cargo shipped by each individual (CPCU Journal, 1989). But according to Wheeler (1990), in medieval China, the insurance development was rather limited, mainly because of the lack of contractual arrangements and of the enforcement of agreements to share risk. Between 1911 and 1949, the insurance industry in China was dominated by British companies ${ }^{1}$ and the role of Chinese and other nationals was limited.

The People's Insurance Company of China (PICC) was created in 1949, after the communists took power. For a long time, it was the only authorised insurance company to operate in China. From 1959 to 1979, political upheavals, known as "the Great Leap Forwards" and "the Cultural Revolution" halted insurance in most of China. During this time, PICC's business was limited to only a small volume of foreign insurance, mainly marine cargo and aviation insurance. The domestic business, life insurance in particular, was almost dead for twenty years (Wheeler, 1990).

In the 1980's, the insurance industry in China underwent a radical transformation, driven by the political forces of liberalization and the nation's booming economy. The insurance industry in China has developed rapidly, over the past 10 years or so, with premiums jumping from only 640 millions RMB in 1980 to 24 billions $\mathrm{RMB}^{2}$ in 1992 . And the size of the workforce in the industry has also expanded, increasing from about 5,000 employed in 1980 to more than 100,000 in 1993 (Asian Insurance Review, 1-2/92).

Table 1 shows that Chinese premium income grew more than $30 \%$ yearly on average between 1986 and 1992, while the country's GNP grew about $9 \%$ yearly ${ }^{3}$ (see also Figure 1 and 2).

Table 2 demonstrates comparable figures of the Chinese insurance market with those of few other selected markets.

\footnotetext{
1 The establishment of the first British insurer in China dated back to as early as 1835 , when Union Insurance, now merged with Guardian Royal Exchange, set up an office at Canton (now Guangzhou) in southern China (Lloyd's Insurance International, September, 1993).

${ }^{2}$ Official exchange rate of RMB was US $\$ 5.76$ RMB Yuan in 1993, 5.52 in 1992, 5.32 in 1991, 4.78 in $1990,3.77$ in 1989 and 3.72 in 1988. issues).

${ }^{3}$ For the same period, world premium income grew $6-7 \%$ yearly on average. (Sigma, various
} 
Table 1: Direct premium income in Chinese Insurance Market, 1986-1992

\begin{tabular}{llllllll}
\hline & $\begin{array}{l}\text { Total } \\
\text { RMB m }\end{array}$ & $\begin{array}{l}\text { Total } \\
\$ \mathrm{~m}\end{array}$ & $\begin{array}{l}\text { life } \\
\text { RMB }\end{array}$ & $\begin{array}{l}\text { non-life } \\
\text { RMB }\end{array}$ & $\begin{array}{l}\text { growth* } \\
\%\end{array}$ & $\begin{array}{l}\text { density** } \\
\$\end{array}$ & $\begin{array}{l}\% \text { of } \\
\text { GNP }\end{array}$ \\
\hline 1986 & 5,092 & 1369 & 1034 & 4058 & 48.5 & 1.3 & 0.65 \\
1987 & 7,453 & 2002 & 1589 & 5864 & 46.4 & 1.9 & 0.67 \\
1988 & 10,063 & 2704 & 2229 & 7834 & 31.9 & 2.5 & 0.72 \\
1989 & 12,243 & 2593 & 2456 & 9787 & 22.3 & 2.4 & 0.77 \\
1990 & 14,760 & 2826 & 3102 & 11658 & 21.0 & 2.5 & 0.85 \\
1991 & 18,195 & 3348 & 4226 & 13969 & 23.1 & 2.9 & 0.90 \\
1992 & 24,000 & 4211 & 7500 & 16500 & 33.1 & 3.8 & 1.00 \\
\hline
\end{tabular}

Source: Sigma, Asian Insurance Review, PICC annual Report, various issues.

* growth rates of RMB premium income over previous year.

** premium earned per head.

Figure 1:

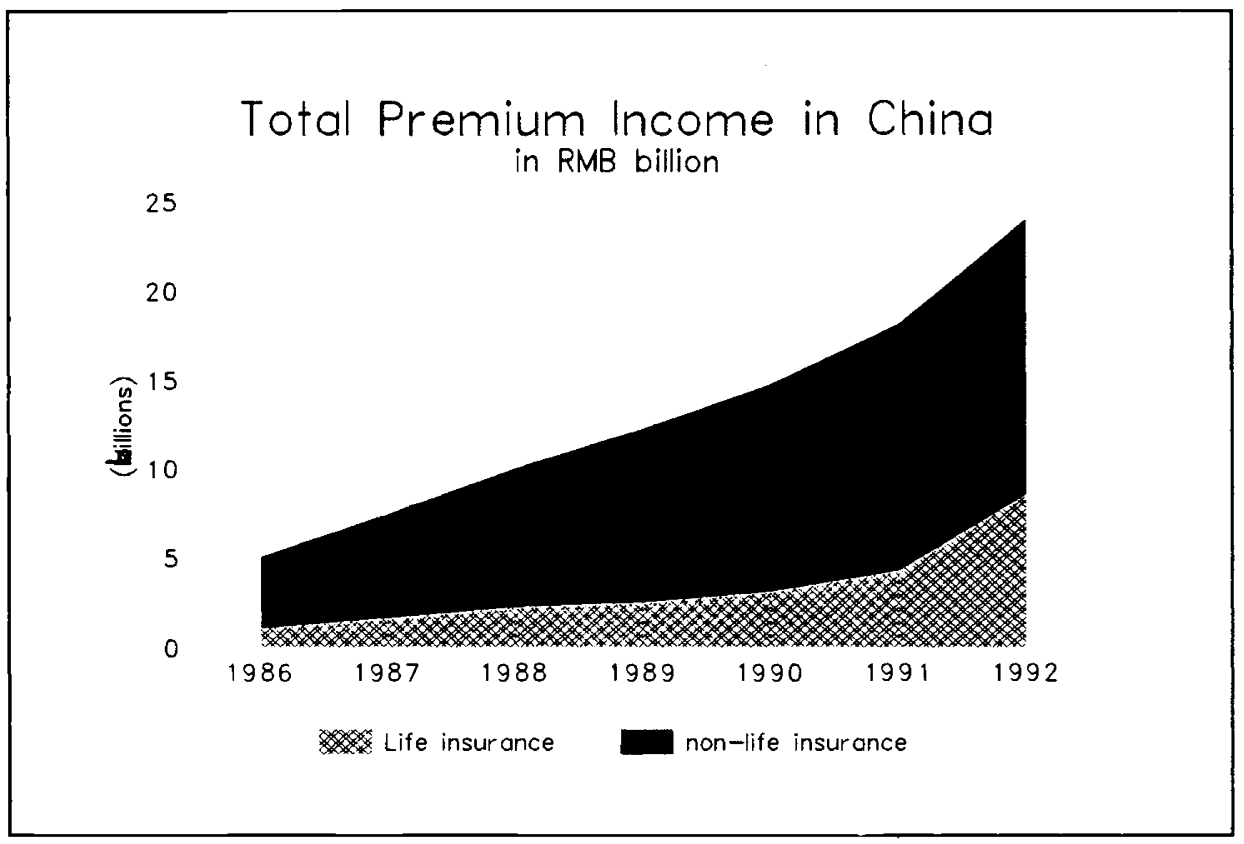


Figure 2:

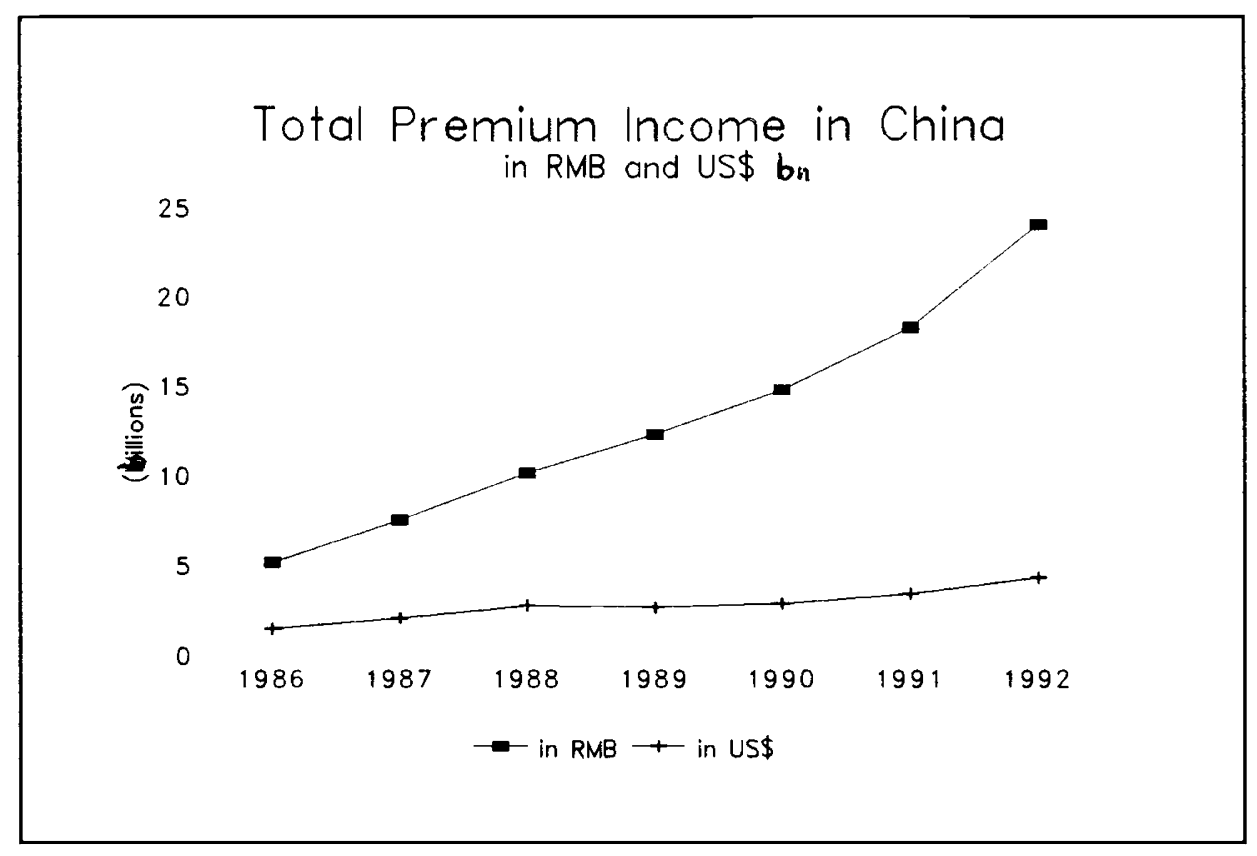

Table 2: International Comparison of the Chinese Insurance Market, 1991, US \$

\begin{tabular}{|c|c|c|c|c|c|c|}
\hline & $\begin{array}{l}\text { Total } \\
\text { Premium \$m }\end{array}$ & $\begin{array}{l}\text { Life } \\
\text { business \%* }\end{array}$ & $\begin{array}{l}\text { Density } \\
\$\end{array}$ & $\begin{array}{l}\text { Penetra- } \\
\text { tion \% }\end{array}$ & $\begin{array}{l}\text { World } \\
\text { share \% }\end{array}$ & $\begin{array}{l}\text { World } \\
\text { Rank }\end{array}$ \\
\hline China & 3,094 & 23.2 & 2.9 & 0.9 & 0.22 & 25 \\
\hline Mexico & 3,533 & 35.6 & 40.2 & 1.3 & 0.25 & 24 \\
\hline India & 3,966 & 67.9 & 4.7 & 1.7 & 0.24 & 23 \\
\hline Taiwan & 8,254 & 69.7 & 402.6 & 4.5 & 0.58 & 18 \\
\hline S. Korea & 31,702 & 80.3 & 732.7 & 11.6 & 2.24 & 8 \\
\hline
\end{tabular}

Source: Sigma, $4 / 93$

* share of life insurance in total business.

It is expected that China will achieve a gross premium income level at $180-200$ bn RMB by 2000 (US $\$ 36 \sim 40$ bn at 1992 exchange rate) which will then include China among 
the 10 biggest insurance markets ${ }^{4}$ Another source, quoted from Mr. Henri de Castries, executive vice president of AXA, has predicted that China could become the largest life insurance market in the world in 30 or 40 years (EuroBusiness, Dec. 93/Jan. 94).

The state-owned insurer, the People's Insurance Company of China (PICC) still dominates the domestic market. According to one estimation, more than $90 \% \sim 95 \%$ of the business in the market is held by PICC (IRL, Sep. 93). In 1992, PICC employed a workforce of 80,000 , opened more than 3000 branches nation-wide, and had more than 60 foreign branches to write business (mainly in Hong Kong and Macau). It also has offices in UK, USA, Germany, Japan, and Luxembourg (IRL, March 93).

Table 3: PICC's key statistics, 1980-1992, RMB m

\begin{tabular}{rcccccc}
\hline & $\begin{array}{l}\text { Total } \\
\text { Premium }\end{array}$ & $\begin{array}{l}\text { Non-life } \\
\text { claim }\end{array}$ & $\begin{array}{l}\text { Investment } \\
\text { revenue }\end{array}$ & Reserve & $\begin{array}{l}\text { Profit } \\
\text { /Loss }\end{array}$ & $\begin{array}{l}\text { Total } \\
\text { Assets }\end{array}$ \\
\hline 1980 & 640 & - & 36 & 285 & 70 & 1047 \\
1981 & 940 & - & 56 & 333 & 117 & 1452 \\
1982 & 1130 & - & 61 & 375 & 289 & 2243 \\
1983 & 1450 & - & 93 & 581 & 392 & 2807 \\
1984 & 2010 & - & 271 & 660 & 561 & 3467 \\
1985 & 3200 & - & 432 & 1005 & 791 & 4745 \\
1986 & 5030 & - & 542 & 1218 & 1014 & 6636 \\
1987 & 7410 & 2754 & 627 & 1511 & 1457 & 9732 \\
1988 & 10030 & 3653 & 768 & 1733 & 1906 & 13692 \\
1989 & 12242 & 4730 & 1055 & 1040 & 2436 & 17413 \\
1990 & 14659 & 5349 & 1051 & 3190 & 3511 & 23842 \\
1991 & 18195 & 8262 & 1512 & 3593 & 2238 & 35157 \\
1992 & 23806 & 15072 & 1952 & - & 2283 & 48008 \\
\hline
\end{tabular}

Source: PICC Annual Report, various issues.

Figure 3 shows two key ratios of PICC between 1980 and 1992.

Compared with the similar figure on the underwriting ratio of UK leading non-life insurance companies at same period (Figure 4), ${ }^{5}$ we remark that the business operation of PICC was exceptionally profitable for a number of reasons. First, the Chinese insurance market is a rapid growing market and the demand exceeds the supply of insurance available in the market. PICC's premium income has grown between $21 \%$ and $60 \%$ since 1980 , and such a high growth rate has meant that its premium income can easily more than cover its exposure in the previous years. Second, PICC largely maintained its monopoly in the

4 These statement and estimation are based on the quantitative assessment technique used in Sigma, 6/92, with regards to East Asian and Latin American insurance development, assuming the chinese GDP growth rate till 2000 will be of the same range as for the 1980 's.

${ }^{5}$ This figure is being used by courtesy of Dr. S. Diacon. 
Figure 3:

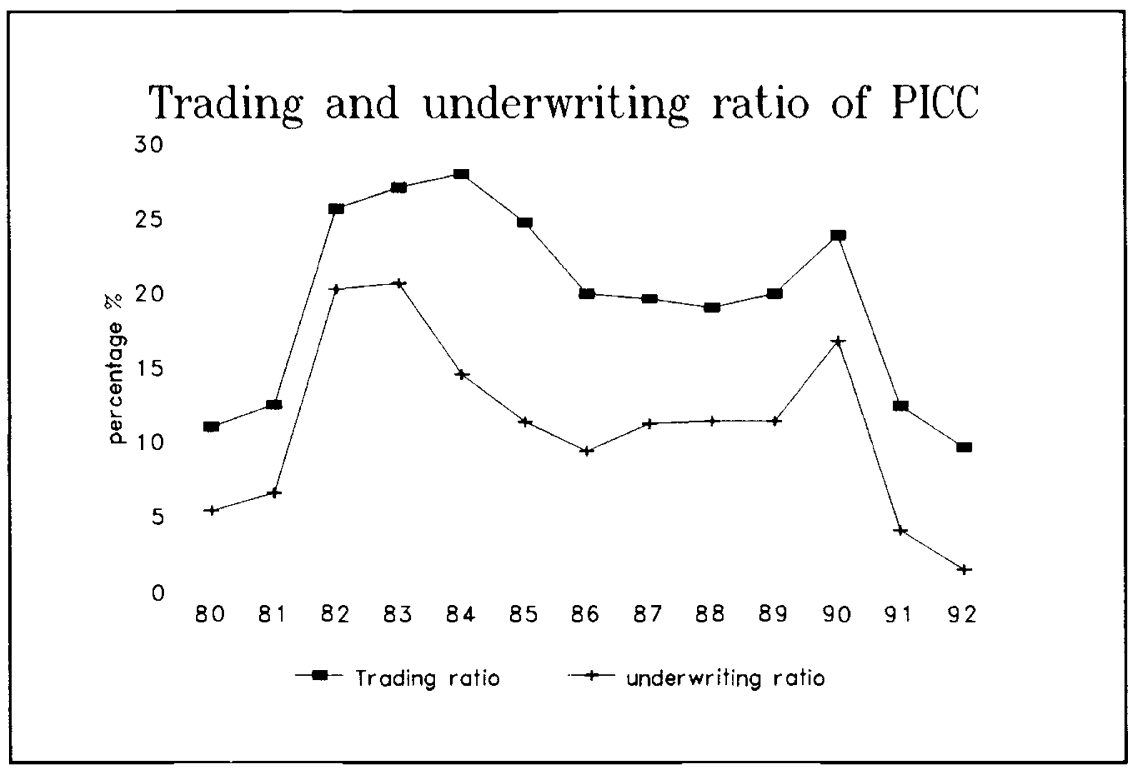

Figure 4:

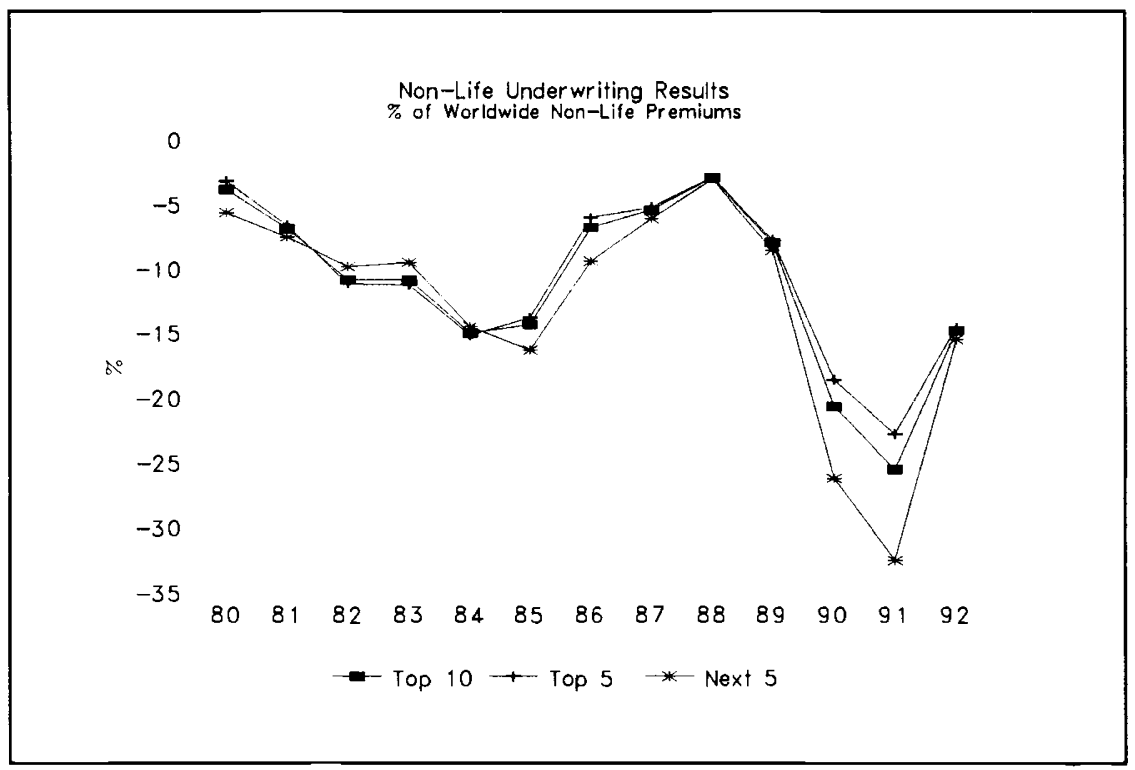


market during this period, and its high profit can be considered as the result of its monopolistic domination. Third, the Chinese government, being the sole owner of PICC, has granted an annual capital input into the reserve fund of PICC for many years, while it has eased the pressure on PICC to build up reserve by its own means, and thus increased the overall trading results. The downward trend of the figure since 1990 reflects the increasing competition and the diminution of government's capital injection in the last few years.

Since 1988, the monopolist power of PICC has been reduced, since other domestic insurers have been authorised to underwrite insurance business. However, the monopoly position of PICC is still guaranteed by the present regulation, and the 1985 Provisional Ordinance of Insurance Enterprise gives special treatment to the PICC. Some businesses shall be exclusively transacted by the PICC, including compulsory insurance, insuring foreign currencies, insuring foreign enterprises and joint-ventures, and international reinsurance. Under the new competition, the restrictions on the PICC's exclusive rights on foreign and joint-venture enterprise, on state-owned enterprise, and on foreign currencies have relaxed in favour of newly-established domestic insurers.

In early 1993, there were 18 domestic insurance companies -8 in life business and 10 in non-life business (see Appendix 1). Most of the newly established insurance companies are simply regional branches of PICC which have acquired independent status as its tied subsidiaries, such as Beijing Insurance Company. But the genuinely independent companies are:

- China Pacific Insurance Company (CPIC) with its headquarters in Shanghai. Its sole owner is the Bank of Communications in Shanghai. It is very active in products innovation, marketing, and in commercial property and liability insurance, and may soon become a major national insurer.

- Ping An Insurance Company (PAIC) in Shenzhen is jointly owned by the Chinese Merchants Group in Shenzhen, Bank of Commerce in Hong Kong and the Shenzhen Bank of Commerce and Industry Investment Corporation. It has recently set up a regional operation center in Beijing, and another in Shanghai, marking a direct challenge to PICC.

- Xing Jiang Agriculture Insurance in Xing Jiang Province. It was founded by the Authority of Xing Jiang Agricultural Production, which is a state-owned agricultural unit operating in Xing Jiang Province at North-West of China. The business of Xing Jiang Agricultural Insurance focuses on crop and agriculture-related insurance.

In addition, China Reinsurance Company is an independent subsidiary of PICC, with overall responsibility for reinsurance both within and beyond Chinese borders. Its subsidiary in Hong Kong - China Re. (Hong Kong) - is expanding quickly and may become a major force in the Hong Kong reinsurance market (World Insurance Report, 7 May 1993). A plan is also in its initial stage to split up PICC's life and general insurance business in the future, and then to form two independent subsidiaries under the auspices of PICC Holdings (The People's Daily, 10th January 1994).

Another important structural characteristic of the Chinese insurance market is that duopoly competition is emerging in certain regions (i.e. Shanghai, GuangDong) and certain sectors (i.e. aviation liability insurance) with other new established insurers, such as Ping An, and Chinese Pacific in particular, seeking to gain market share and demonstrating dramatic growth.

During the last decade, the insurance products in China have been modernised considerably. In 1992 more than 300 insurance products were available in the market, covering a 
wide range of business, including life and health insurance, personal and commercial property insurance, agriculture insurance, personal and commercial liability insurance, international property and liability insurance, and reinsurance. Some new innovative products have also appeared, such as pension funds for peasants and collective enterprise's workers, rural enterprises insurance, insurance for joint-venture, cooperation and sole ownership, deposit-linked children endowment, long-term household insurance, political-risk insurance, venture capital insurance, nuclear power station insurance, and satellite launch insurance.

The life insurance sector has grown very fast in last two years. In 1992, the premium income of the life sector reached RMB 7.5 billion, jumping $77 \%$ higher over 1991 . There are two reasons for this rapid growth. First, the increased employees in foreign-owned, joint-venture and private-owned enterprises, who are not covered by the state-run universal social security system, have to participate to the pension schemes or buy other types of long-term insurance products offered by insurance companies. And second, the marketing effort and upgrading of life policies (such as simplifying procedure, assuring return of premium with additional saving) gives customers incentive to buy the life insurance products (Asian Insurance Review, 7-8/93).

\section{Strengthening of the insurance legal framework}

To date there have been few laws and legislations relevant to insurance:

- Economic Contract Law, 1981.

- Property Insurance Contract Ordinance, 1983.

- Provisional Ordinance of Insurance Enterprise, 1985.

- Marine Commercial Law, 1985.

The insurance sector is presently controlled by the Provisional Ordinance of Insurance Enterprises issued by the State Council in 1985, which does not apply to the social security system.

The people's Bank of China (PBOC), acting as the state insurance regulatory body, administers the 1985 Insurance Ordinance. The PBOC has widespread power to licence the establishment of insurance firms, to decide on the insurance classes and premium rates, to inspect and audit accounts, statements and certificates of insurance enterprises, and to impose sanctions on insurance firms including ordering their winding up.

The provision of insurance is very strongly controlled by the government, and all property owned by the state, collective or individual must be insured with companies registered and authorised to operate in China.

A comprehensive and updating insurance law has been drafted and was submitted for approval by the National People's Assembly (Chinese Parliament) in Spring 1994. The new insurance laws could affect a complete change in the Chinese insurance industry (Risk Management, 1992). Principal points of difference from the previous regulations are:

- Total separation of life and property insurance,

- Differentiation of commercial and social insurance, since the latter is not included in the new insurance laws, ${ }^{6}$

\footnotetext{
${ }^{6}$ The following classes are not included in the new insurance laws (Art. 11):

* Social security, which is subject to other laws and regulation,

* Credit insurance for export,

* Protection and indemnity insurance arranged through ship owners' clubs and associations,

* Group welfare arranged by an organisation for its staff and members.
} 
- Creation of a special state authority for insurance supervision - the State Bureau of Administration of Insurance (State Insurance Bureau),

- Foreign insurance companies will be allowed to enter the Chinese market,

- Market entry condition is tightly regulated,

- Detailed technical requirements of supervision will be issued by the State Insurance Bureau after approval of the Insurance Law,

- Insurance agents and brokers will be subject to another special regulation.

In the Draft Insurance Law, the State Insurance Bureau is given extensive power to intervene and supervise insurance companies in China. Its responsibilities are to:

- Draw up guidelines and policies for the national insurance industry,

- Draw up administrative rules and regulations,

- Examine and approve the establishment and winding down of insurance institutions,

- Examine and approve the registration of insurance agents and insurance brokers,

- License the establishment of insurance businesses,

- Supervise and administer insurance activities, and correct and impose sanctions on illegal activities,

- Correct and impose sanctions on non-insurance institutions which carry out insurance business.

At the present stage, the Draft Insurance Law is divided into five sections, namely: general principles, contract law, administration and regulation of insurance firms, the penalties for breaching of the insurance law, and supplementary rules. The principal regulation under the Draft Insurance Law will be summarized under the following headings: licensing, solvency, reserve and investment requirements and contract and premium regulation.

\section{Licensing}

The insurance firms in China will be classified as state-owned, share capital, mutual, cooperative insurance companies, and branches of foreign insurers (Art. 97). ${ }^{7}$ To get an insurance licence, companies must apply for approval from the State Insurance Bureau. The following conditions must be completed:

(a) The set-up capital requirement: 100 million RMB for state-owned and share capital company, 50 million for mutual company (Art. 106).

(b) Neither government organisations nor private individuals are allowed to operate insurance businesses (Art. 107). Banks or subsidiaries of banks are not allowed to set up an insurance business (Art. 108).

(c) The overall business is divided into 12 classes of general insurance and 7 of life insurance (Art. 98), the operation of each class is subject to approval by the Draft Insurance Law. The general insurance firms are allowed to conduct only some classes of life insurance (i.e. personal accident insurance and health insurance). Firms doing life insurance are not allowed to conduct general insurance (Art. 99).

(d) The company must provide a Memorandum of Association, a report on business feasibility, proof of paid-up capital, and a list of key personnel (Art. 103-104).

\footnotetext{
7 The article's numbers of the Draft Insurance Law may change in the final version.
} 
(e) A guarantee fund must be established of $20 \%$ of the firm's set-up capital, which must be deposited at a bank specified by the State Insurance Bureau. The $20 \%$ rate criterion is only applicable for domestic insurance firms, while the criterion for foreign insurers has to be decided by the State Insurance Bureau.

(f) A normal license for conducting business must be obtained (Art. 109-114).

Solvency, reserve and investment

The minimum solvency margin will be laid down by the State Insurance Bureau. The reserves of insurance firms must cover the future liabilities, outstanding claims, as well as a special reserve and a general or statutory reserve (Art. 149).

The reserves for future liabilities of general insurance must equal $50 \%$ of the present year's received premium, while the reserves for future liabilities for long-term insurance must equal the total net value of the valid long-term life policies. Reserves for outstanding claims must equal the sum of outstanding claims and an amount for recent losses. The special reserve must be $1 \%$ of the present year's premium: it must be accumulated year after year and can only be used with the State Insurance Bureau's consent. The general reserve must not include any amount that should have been appropriated for taxation provisions or other reserves: the amount of the general reserve will be specified by the State Insurance Bureau.

Furthermore the composition of insurance company's investments will be decided by the State Insurance Bureau (Art. 168-173).

\section{Premium and contract regulation}

The contract (including the term, premium rate and policy format) and any changes must be submitted to the State Insurance Bureau for approval. The Bureau deserves also the right to draw up example contracts and example premium rates.

One report in Asian Insurance Review (July/August 1993) points out that the Draft Insurance Law is drawn from the insurance laws of 16 foreign countries, including Germany, France, UK, New York State of US, Japan, and several Asian countries. An international comparison of the set-up capital and guarantee fund requirement is provided in Table 4.

Table 4: Comparison of set-up capital and guarantee fund requirements, US \$ million

\begin{tabular}{|l|c|c|c|}
\hline & Life & Non-life & $\begin{array}{c}\text { Guarantee fund } \\
\text { (\% of set-up capital) }\end{array}$ \\
\hline China & $11.5 / 5.7 \mathrm{~m}^{*}$ & $11.5 / 5.7 \mathrm{~m}^{*}$ & $20 \%$ \\
UK & - & - & $0.7 / 0.35 \mathrm{~m}^{* *}$ \\
Canada & $4 \mathrm{~m}$ & $3.3 \mathrm{~m}$ & - \\
Taiwan & $4 \mathrm{~m}$ & $4 \mathrm{~m}$ & $15 \%$ \\
\hline
\end{tabular}

* requirement for state and share capital company and mutual company respectively, using February 1994 exchange rates: US $\$ 8.7$ RMB Yuan.

** for life and non-life business respectively.

Source: Chinese Draft Insurance Law, Handbook of Insurance, 1993, KPMG, 1991. All requirements in local currencies are converted into current US Dollars. 
Table 4 shows that the set-up capital and guarantee fund requirements in the Draft Insurance Law will be relatively high. New market entry is thus deterred and only companies with a strong capital base may hope to obtain licences. Although there is a promise of non-discrimination against foreign insurers (WIR, 07 May, 1993), the requirements for foreign insurance companies to establish in China are still not clearly defined in the Draft Insurance Law.

\section{Opening up to foreign insurance forces}

Given the potential of the Chinese insurance market, many foreign insurers are waiting to open its doors and enter the market. By 1993, about 50 foreign insurers applied for insurance licences in China (see Appendix 1).

At the present time, only three foreign insurers and brokers have succeeded in getting licences. Early in October 1992, approval was given to the first foreign owned insurance company - American Insurance Assurance, a subsidiary $100 \%$ owned by American Insurance Group (AIG). It was allowed to write property and personnel insurance in the city of Shanghai. Once its presence there has been consolidated, AIG plans to apply for further licences in Beijing, Guangzhou and the five special economic zones. It launched its business with 22 sales staff and plans to build it up to around 300 soon. The licensing condition required AIG to invest income generated from business into the local market for at least ten years (Yeung and Savic, 1993).

Early in 1993 , another licence was issued to a subsidiary $60 \%$ owned by $\mathrm{M}$. Thai Group of Thailand to write life and non-life insurance business based at Putong, Shanghai. The group is an agriculture property-based conglomerate, with no experience in the insurance industry.

Sedgwick Group became the first insurance broker to be granted a full licence to operate throughout China in late 1993. However Sedgwick Insurance and Risk Consultant (China) Ltd., a wholly subsidiary of Sedgwick Group (UK), opened its liaison office in Beijing in 1981 for market research and consultancy.

Further authorizations are likely to be issued in 1994 or 1995 , probably after approval of the new insurance law and relevant regulations. Mr. Qing Daofu, who was Chairman of PICC and is now in charge of drafting the Insurance Law, pointed out that China will only allow entry of foreign insurers on a "selective and planned" base (People's Daily, 5/12/93). According to Mr. Li Yuming, Chairman and chief executive of PICC, China is expected to join GATT before the end of 1994, and its insurance market will then open gradually - first to US and Taiwanese companies, then to European and Japanese companies. The licences issued will initially be limited to coastal cities and then extended to inland provinces (Central Daily, 20 January 1994).

Chinese insurers, led by PICC, are also seeking to enter the world insurance market. Through commercial links and direct establishment, PICC has over 300 agencies in more than 100 countries and regions, including offices in New York, London, Tokyo, Hamburg and Luxembourg. Its main target markets are Hong Kong, South-East Asia, USA and Europe. Ping An Insurance Company operates a fully-owned subsidiary in United States at Delaware. China Pacific Insurance Company is planning to open an office in the USA (The People's Daily, December 16, 1993).

Among the principal target markets, the strategic position of Hong Kong is specially vital for the Chinese insurance industry, before and after 1997. More than 280 authorised 
insurers concentrate in Hong Kong (ReActions, 1990), making it one of the most liberal and competitive insurance markets in the world. Chinese insurers are already established in Hong Kong, being aware of its position as a port of entry to the world's financial market, and the insurance market in particular. One estimation believes that Chinese- related companies control at least $25 \%$ of non-life business in Hong Kong (Golden, 1994). In reverse, many well-known names in the insurance industry worldwide have a presence in Hong Kong to profit from its sophisticated infrastructure for business and to exploit its unique position for China. Hong Kong may well become the insurance and reinsurance centre for China in the late 20th century (Batchlor, 1990).

In order to support the long-term prosperity of the company, PICC is actively engaged in a professional development project in collaboration with foreign insurance forces. The UK insurance industry and London insurance market are particularly active as partners. The Chartered Insurance Institute of UK (CII) and the Lloyd's of London have helped PICC's selected staff, including some senior managers, to improve their professional education. Other UK insurance companies and brokers (such as Guardian Royal Exchange, General Accident, Sedgwick, Eagle Star, Sun Alliance and Willis Corroon) have also participated in PICC training projets, in the UK as well as in China. Other newly-established companies, such as China Pacific Insurance Co. and Pin An Insurance Co., are also engaged in professional training programmes, with help coming from foreign insurance companies and institutions.

PICC runs a College of Insurance at Changsha for professional training. Supported by the Society of Actuaries (SOA) of US, Nankai University in Tianjing also started a postgraduate actuarial science course since 1988: the first 15 students completed this three years' Master's degree programme in Autumn 1991, and a second three-years cycle began then (Tuan, 1993). Another actuarial course was started in 1993 at the Central Institute of Finance and Economics, Beijing, with the participation of foreign experts from Eagle Star and the Institute of Actuaries of UK. Meanwhile, some leading universities and research institutions in the country, including Beijing University, People's University in Beijing, Fudan University in Shanghai and the Chinese Academy of Sciences (Academia Sinica) have begun to conduct higher educational and research programmes in insurance economics, risk management and actuarial science.

There are two main obstacles to the Chinese insurance industry's international integration. First, the Chinese insurance firms will find it difficult to sell insurance to foreign companies operating in China or to enter the world insurance market. Second, the market and legal conditions in China still make it difficult, if not impossible, for foreign insurers to penetrate into the promising Chinese market. According to a report conducted of in the mid-Eighties by AIG, $50 \%$ of the US joint ventures in China did not purchase insurance coverage from Chinese insurers, even though the present laws prevented them from buying coverage from overseas. Many foreign investors are buying insurance outside China on a non-admitted basis (Batchlor, 1990) because the political risk, and the unsophisticated legal system, discourage potential foreign customers from using the services provided by Chinese insurers. Furthermore, although most coverages are available through the Chinese insurance market, the policy design and wording are sometimes outdated and not always easily understood by foreign clients. In addition, the customer service, lack of appropriate, qualified and experienced staff and the language barriers may deter some foreign customers. 
For the foreign contender willing to entry the Chinese insurance market, the prime obstacle is the legal barrier. Under the present regulation in force (1985 Provisional Ordinance of Insurance Enterprise), foreign insurers are prohibited for doing any business in China. The international reinsurance business also monopolised by PICC under the special treatment of law. Even under the Draft Insurance Law, the reinsurance business must mainly remain in the country, since reinsurance may arrange with a foreign insurer only with the special approval of the State Insurance Bureau (Art. 155). Under the Draft Insurance Law, the foreign insurance institution must employ a Chinese citizen who resides in China as a representative, and require a normal permit to conduct business. However, the Draft Insurance Law does not determine clearly the condition and capital requirements ${ }^{8}$ for branches of foreign insurers in China.

\section{The shape of the future}

In general, the function of the insurance industry in a developing economy is often outlined as the mechanism to control the risk in economic development, the financial intermediator to channel savings toward investment and the contribution for the pension and social security system. ${ }^{9}$

Policy initiatives aimed at turning insurance into a key sector of the country's service industry have been underway for some time in China. The tasks facing the Chinese insurance industry are basically the same as in other developing countries, in particular newly industrialising countries. ${ }^{10}$ They turn to be favourable factors for its potential development.

In China, enormous geographical scale and diversification, and the large size of its population make large scale risk management not only desirable but indispensable. In addition, high economic growth and technological upgrading, increasing aggregation and complexity of social risk are increasing the demand for an innovative and extensive insurance industry.

In the context of financial liberalisation China, insurance companies are expected to act as major institutional investors, mortgage lenders in the emerging private property markets, and financial intermediaries in the private capital investment market. In China, the household saving ratio is remarkably high - more than $30 \%$ of current GDP, with total bank deposits over 1500 bn RMB in 1993 (US $\$ 260$ bn).

Population projections demonstrate that China will have more than $10 \%$ population of 60 years of age in the years 2000 , and the expected annual pension payment then will exceed 110 billions RMB. The old-fashioned universal retirement system in China will not be able to cope. Furthermore, an increasing proportion of the population is working in the private and foreign-owned sector, and is not covered by the state-pension scheme: hence alternative schemes must appear. There is also an increasing demand for private health insurance schemes.

8 According to an officer of PICC, foreign insurers are likely to have to provide assets in lieu of capital as a guarantee fund under the new insurance laws (WIR, 07 May 1993).

9 See Skipper, 1987, Outreville, 1989 and Carter and Dickinson, 1992.

${ }^{10}$ Sigma, 6/92 addressed the insurance industry in two newly industrialising regions: East Asia and Latin America and gives an overall picture of insurance development in those economies. 
In fact, the Chinese government has already begun to establish pension fund companies at the provincial level, and some have already started operating (i.e. Beijing, Tianjing, etc. ). ${ }^{11}$ The new pension system will help workers to shift from national retirement and pension schemes to company pension schemes, and even to private pension schemes. China will also offer unemployment insurance to all urban workers, including those in the foreign-funded and private business - starting in 1995. It should be noted that the present unemployment insurance system only covers the state sector in a limited scale (Asian Insurance Review, 9/10/93).

Despite the magnificent development and the promising future of the Chinese insurance industry, there are still some weaknesses running on. First, despite the training provided by domestic insurers and supported by their international partners, the shortage of experienced insurance personnel in China is damaging the industry's expansion ambition. The supply of appropriate marketing managers, accountants, actuaries, risk management experts, financial advisers, and legal experts dealing with insurance issues, is lagging behind the increasing demand, both in the domestic and international market. Thus in the highly technical domain of insurance business (i.e. actuarial science, risk adjustment and longterm financial planning, including computerization of business), technology and know-how transfer may be vital.

Secondly, due to relatively short history of the revitalised Chinese insurance industry, large-scale, complex and tailored insurance products (in particular in the commercial and international lines) are still underdeveloped. In the life branch, insurance companies in China should be able to offer more up-to-date financial products, in particular in long-term life insurance, to meet the increasing demand by wealthier customers and elder population.

Finally, despite the efforts to set up and enforce the legislation and regulation, the defects and ambiguities of the insurance legal system leave lot of room for improvement. In general, the whole legal framework for modern economic and managerial practices in China still has to be established and strengthened, ${ }^{12}$ and the tax system and juridical arbitration for insurance still have to be clarified and enhanced.

${ }^{11}$ See Hussaian, 1993, on general discussion on the reform of the Chinese social security system.

${ }_{12}$ Note that a new unified tax system was already phased in 1994, including the renovated tax on corporations, on personal income and capital gain, on property transaction and on insurance (see Financial Times, 2nd December, 1993). 


\section{REFERENCES}

ASIAN INSURANCE REVIEW, various issues.

BATCHLOR, David (1990) "Solving the Chinese Puzzle", ReActions, November.

CPCU Journal (1989) "Insurance in China", Vol. 42, June. pp. 105-111.

CARTER, R. ed. (1993) Handbook of Insurance", Kluwer.

CARTER, R. and DICKINSON, K. (1992) Obstacles to the Internationalization of Insurance, Trade Policy Research Center, London.

Draft Insurance Law of China, Translated from Chinese in July 1993.

GOLDEN, Jeremy (1994) "Nothing minor about Asia“, Reinsurance, January.

HUSSAIN, Athar (1993) Reform of the Chinese Social Security System, CP. No. 27, STICERD, London School of Economics.

Insurance Research Letters (IRL), various issues.

KPMG (1988) Insurance Company Financial Reporting Worldwide.

Lloyd's Insurance International, various issues.

OUTREVILLE, Jean-François (1989) "Trade in Insurance Services", in Trade in Services: Sectoral Issues, United Nations, UNCTAD/ITP/26, New York.

PICC Annual Reports, 1987, 1988, 1989, 1990. 1991.

Risk Management (1992) "Changes in Chinese Insurance Industry", Vol. 29, December.

ReActions (1990) "Hong Kong: Still a Higher Flyer", November.

Reinsurance (1993) "The years of the reinsurer", April.

Sigma, various issues.

SKIPPER, Harold (1987) The Promotion of Risk Management in Developing Countries, Committee on Invisible Trade and Finance, UNCTAD. TD/B/C. 3/218, Geneva.

TUAN, K. (1993) "Impact of SOA-Nankai actuarial program is far-reaching", The Actuary, October.

WHEELER, Jack (1990) “A new world power in insurance emerges”, ReActions, 1990, pp. 225-227.

World Insurance Report (WIR), various issues.

YEUNG, Desmond and SAVIC, Bob (1993) "China - Open for Business", European Insurance Bulletin, Autumn, Touche Ross. 


\section{Appendix 1. Major Insurance Organisations in China}

1. Domestic companies:

People's Insurance Company of China (PICC)

Beijing, State owned, 1949

Market share : $90 \approx 95 \%$

China Pacific Insurance Company (CPIC)

Shanghai, owned by Bank of Communications, 1991

Ping An Insurance Company (PAIC)

Shenzhen, owned by China Merchant Group, 1991

Xin Jiang Agriculture Insurance Company, 1991

Urmuqi, owned by the Authority of Xing Jian Agriculture Production and Xing Jian Province.

2. Foreign Company:

American International Assurance (AIA) Ltd.

Shanghai, 1993, 100\% subsidiary of AIG, US.

M. Thai Insurance Ltd. Shanghai, Sino-foreign joint venture, $60 \%$ owned by

M. Thai Group Thailand

3. Foreign Broker:

Sedgwick Insurance and Risk Management Consultant (China) Ltd.

Beijing, 1993, 100\% subsidiary of Sedgwick Group, UK

4. Proposed companies:

CITIG Insurance Company, owned by CITIC (China International Trust and Investment Corporation) Industrial Bank, Beijing

Aijian Insurance Company, by Aijian Commercial Bank, Shanghai

5. Education and Research

(1) Professional Training:

Changsha College of Insurance, (PICC), Changsha

(2) Research Institution:

PICC Insurance Institute, Beijing

(3) Higher education:

School of Economics and Management, University of Beijing, Beijing

Central Institute of Finance and Economics, Beijing

Nankai University, Institute for Advanced Study in Economic Security, Tianjing

School of Economics, Fudan University, Shanghai

(6) Foreign Links :

(1) Chinese insurance firms abroad:

UK: China Insurance Co. (UK), by PICC, London

US: Chinese American Insurance Company (CAIC), Joint-venture between PICC and AIG, New York

Ping An Insurance (USA) Co. Ltd. Delaware 
Hong Kong: Ming An Insurance, owned by PICC

ChinaRe. owned by PICC, Ming An Insurance and Tai Ping Insurance.

Guangdong Asia Insurance Company.

CJM Insurance Broker, joint-venture between Bank of China, Jardine

Insurance Brokers (HK), Ming An Insurance (overseas)

Bank of China Group Insurance (Hong Kong), owned by Bank of China

(2) Major foreign partners:

UK: Lloyd's of London, The Chartered Insurance Institute, Eagle Star, Prudential Sun Alliance, Guardian Royal Exchange, General Accident, Willis Faber, Sedgwick, Bowring, The Institute of Actuaries.

US: Continental, Chubb, CIGNA, Johnson \& Higgins, Alexander \& Alexander, March \& McLennan, AIG, Aetna, Mutual Life Insurance, Society of Actuaries.

Switzerland: Zurich Insurance Co.

Hong Kong: Lombard Insurance Group.

Japan: Sumitomo Marine and Fire, Tokio Marine and Fire, Tri-well Marine and

Fire, Yasuda Fire and Marine, Nippon Life, Mitsui Mutual Life. 